О.О. Дробахін, Н.А. Гук, М.О. Ткаченко Дніпровський наиіональний університет імені Олеся Гончара

\title{
АВТОМАТИЗАЦІЯ РЕЙТИНГОВОГО ОЦІНЮВАННЯ ДІЯЛЬНОСТІ НАУКОВО-ПЕДАГОГІЧНИХ ПРАЦІВНИКІВ
}

У статті розглянуто рейтинговий підхід до оцінювання діяльності науковопедагогічних працівників закладів вищої освіти та питання його автоматизації. Запропоновано модель автоматизованої системи рейтингової оцінки діяльності викладача, методику формування рейтингу, архітектуру системи, розглянуто особливості реалізації системи. Проведено аналіз результатів за узагальненими даними по групам посад, по кафедрам, факультетам.

Ключові слова: рейтинг, інформаційна система, ключові показники ефективності, метод суми місць, ранжування.

\author{
O.O. Drobakhin, N.A. Guk, M.O. Tkachenko \\ Oles Honchar Dnipro National University
}

\section{AUTOMATION OF RATING EVALUATION OF SCIENTIFIC AND PEDAGOGICAL EMPLOYEES}

The rating approach to assessing the activities of scientific and pedagogical staff of higher education institutions and the issues of its automation are considered in the article. The model of an automated rating system for evaluating a teacher's activity, a rating formation methodology, and the system architecture are proposed. Features of the implementation of the system are considered. The analysis of the results according to the generalized data on the groups of positions, departments and faculties is carried out.

The most successful approach for assessing the diverse activities of research and teaching staff is the rating approach. The need for rating assessment of scientific and pedagogical staff is provided for the Laws of Ukraine "On Education", "On Higher Education".

The development of a comprehensive approach and methods for assessing the level of competence and qualifications of research and teaching staff is the purpose of the paper. A system of indicators that characterize the activities of research and teaching staff are developed. Integrated types of professional activity (educational-methodical, scientificinnovative and organizational-educational work) are subject to evaluation. The values of rating indicators for different types of activity are determined in different units, so the values are normalized. The sum of places method is used to calculate the rating. The use of weights in the criterions will allow determining the priority kind of activity. Initially, the ranking of all employees for each type of professional activity occurs. Next, the final rating score is defined as the sum of the places in the ratings.

The rating of the professional activity of the head of the department and the dean is calculated taking into account the points of subordinates.

The information system was developed using Python 3.9, the Django Web Framework 3.2 framework and the SQLite3 relational database. The developed methodology and relevant software have been implemented in the activities of Oles Honchar Dnipro National University. Processing and analysis of the obtained results is carried out.

(C) Дробахін О.О., Гук Н.А., Ткаченко М.О., 2021 
Keywords: rating, information system, key performance indicators, sum of places method, ranking.

\author{
О.О. Дробахин, Н.А. Гук, М.О. Ткаченко
}

Днипровский национальный университет имени Олеся Гончара

\title{
АВТОМАТИЗАЦИЯ РЕЙТИНГОВОЙ ОЦЕНКИ ДЕЯТЕЛЬНОСТИ НАУЧНО-ПЕДАГОГИЧЕСКИХ РАБОТНИКОВ
}

В статье рассмотрен рейтинговой подход к оценке деятельности научнопедагогических сотрудников высших учебных заведений и вопросы его автоматизации. Предложена модель автоматизированной системы рейтинговой оценки деятельности преподавателя, методика формирования рейтинга, архитектура системы, рассмотрены особенности реализации системы. Проведен анализ результатов по обобщенным данным для групп должностей, кафедр, факультетов.

Ключевые слова: рейтинг, информационная система, ключевые показатели эффективности, метод суммы мест, ранжирование.

Вступ. Сьогодні актуальними питаннями для розвитку держави $є$ підвищення ефективності системи вищої освіти та якості надання освітніх послуг. При наданні освітніх послуг людський фактор є вирішальним, оскільки саме від праці науково-педагогічного працівника (НПП) суттєво залежить якість знань, які отримають студенти, ефективність впровадження дієвих форм поєднання науки та освіти, інноваційних інтегрованих технологій і методик організації освітньо-виховного процесу, наукової та науково-інноваційної роботи. На шляху до підвищення ефективності системи вищої освіти постає проблема оцінки професійної діяльності викладача.

Найбільш вдалим підходом для оцінювання різнопланової діяльності НПП $\epsilon$ рейтинговий підхід. Рейтингове оцінювання професійної діяльності є формою визначення рівня ефективності роботи, грунтується на принципах об’єктивності, прозорості, гласності, коректності та розраховується на основі узагальненої та систематизованої інформації про результати діяльності упродовж року.

Необхідність рейтингового оцінювання НПП закладу вищої освіти передбачена у Законах України «Про освіту» від 05.09.2017 № 2145-VIII, «Про вищу освіту» від 01.07.2014 р. № 1556-VII, «Положенні про організацію освітнього процесу в Дніпровському національному університеті імені Олеся Гончара», «Положенню про внутрішнє забезпечення якості вищої освіти ДНУ» $[1,2]$. Принципи рейтингового оцінювання викладено також у «Стандартах i рекомендаціях щодо забезпечення якості в Свропейському просторі вищої освіти» (ESG) Свропейської асоціації із забезпечення якості вищої освіти та міжнародному стандарті «Системи управління якістю» ISO 9001:2015 [3].

Аналіз результатів рейтингового оцінювання дозволить керівництву визначати якість кадрового забезпечення освітнього процесу та обгрунтовано приймати рішення щодо матеріального заохочення викладачів. Рейтингове оцінювання має сприятиме мотивації НПП до підвищення рівня професіоналізму та вдосконаленню якості всіх видів професійної діяльності. 
Однак для застосування рейтингового підходу необхідно розробити відповідну методику оцінювання.

Метою роботи є розроблення комплексного підходу та методики щодо оцінювання діяльності науково-педагогічних працівників, за допомогою яких можливо було б визначати рівень компетенції та кваліфікації працівників.

Розробка рейтингової системи оцінювання складається з таких завдань, які необхідно виконати: розробити систему показників, які характеризують діяльність науково-педагогічного працівника; обрати модель формування загального рейтингового балу та метод ранжування показників; розробити інформаційну систему, яка має дружний інтерфейс та надає керівникам відповідних підрозділів доступ до інформації; здійснити збір даних для розрахунку рейтингового балу та обробити результати; здійснити аналіз рейтингових балів науково-педагогічних працівників.

Аналіз літературних джерел. Необхідність оцінювання рівня діяльності персоналу постає практично у кожній сфері діяльності людства, але проблема розробки уніфікованої системи оцінювання, яка б враховувала показники ефективності діяльності, відповідала структурі підприємства та видам робіт персоналу, була зрозумілим та ефективним інструментом прийняття управлінських рішень, залишається досі не вирішеною. Оцінка персоналу є невід'ємним інструментом системи управління людськими ресурсами, тому цьому питанню присвячена достатня кількість робіт [4-6].

У роботі [6] наведено основні групи методів оцінювання якості персоналу, серед яких: якісні методи, використання яких дозволяє порівнювати якості певного працівника з ідеальною моделлю співробітника для тієї чи іншої посади; кількісні методи, за допомогою яких показники діяльності оцінюються у балах або числових значеннях, результати підсумовуються, за впорядкованим списком складається рейтинг працівників; комбіновані методи, які поєднують у собі описові та кількісні аспекти та вважаються найбільш ефективними щодо оцінювання працівників.

Стосовно оцінювання НПП закладів вищої освіти у сучасній літературі наявні поодинокі публікації, у яких ставляться питання формування комплексних оцінок діяльності НПП. Як правило у закладах вищої освіти розробляються власні системи оцінювання, інформація про які викладається у нормативних документах - положеннях про рейтингове оцінювання.

В роботі [7] запропоновано методику рейтингового оцінювання НПП закладу вищої освіти, яка враховує погодинне нормування робочого часу викладача на виконання методичної, наукової, організаційної, виховної роботи та дозволяє співставити об'єм навчальної роботи та інших видів діяльності НПП, встановити акценти на певних видах діяльності, які є актуальними на сьогодні, порівнювати між собою результати робіт за різними видами діяльності. Такий підхід дозволяє уніфікувати нормування різних видів робіт за різними спеціальностями в межах університету, а також порівнювати результати оцінювання НПП з різних закладів вищої освіти. 
У роботі [8] виконано аналіз наявних методів оцінювання компетенцій НПП та визначено їх переваги і недоліки, наведено особливості застосування методик, що впроваджено у діяльність певних закладів вищої освіти для рейтингового оцінювання НПП. Визначено шляхи побудови вдосконаленої системи оцінювання діяльності НПП, в основу якої покладено рейтинговий підхід, що грунтується на результатах експертного оцінювання діяльності НПП всіма учасниками освітнього процесу.

3 огляду існуючих у літературі підходів щодо оцінювання НПП випливає, що розробка адекватних моделей та обгрунтованих методів оцінювання залишається актуальною проблемою, розв'язання якої буде сприяти об'єктивному оцінюванню задля підвищення ефективності праці НПП.

Методика формування рейтингу науково-педагогічного працівника. $\mathrm{V}$ сучасному розумінні рейтинг - це комплексна оцінка стану об'єкту дослідження, яка дає можливість віднести його до певного класу або категорії. Безпосереднє ранжирування $є$ найпростішим способом організації системи рейтингового оцінювання. Сутність цього методу полягає в тому, що об'єкти оцінюються за певними критеріями, потім розраховується сумарне значення показників оцінювання, за результатами яких складається остаточно впорядкований список.

Результати діяльності НПП можуть бути оцінені за допомогою ключових показників, на основі аналізу яких можна зробити ранжування відповідно до отриманих значень. При цьому більш обгрунтованим $\epsilon$ системний комплексний підхід щодо вибору цільових показників, який дозволяє отримати всебічну, інтегровану оцінку діяльності працівника.

При розробці системи рейтингового оцінювання у Дніпровському національному університеті імені Олеся Гончара (ДНУ) вирішено, що оцінюванню підлягають інтегровані види професійної діяльності науково-педагогічного працівника, а також кафедр та факультетів, а саме навчально-методична, науково-інноваційна та організаційно-виховна робота. Окрім загального рейтингу мають відзначатися науково-педагогічні працівники кафедр та факультетів, які займають найвищі позиції у рейтингу з навчально-методичної роботи.

При формуванні рейтингових показників, за якими буде оцінюватися діяльність НПП, необхідно враховувати стратегічні пріоритети закладу вищої освіти, вимоги, за якими здійснюється акредитація освітніх програм, ліцензійні вимоги, що висуваються до науково-педагогічних працівників, а також особливості сфер діяльності кафедр. За результатами аналізу видів діяльності НПП було встановлено, що діапазон видів діяльності є широким, необхідно оцінювати, як статичні показники, наприклад, робота у радах та комісіях, так і динамічні - участь у проектах, видання публікацій, підготовка робіт на конкурс. Крім того, значення рейтингових показників за різними видами діяльності можуть визначатися у різних одиницях вимірювань (кількість, друкований аркуш, відсоток участі, відпрацьовані дні або години). Однак у рейтингової системі оцінювання значення різнопланових показників необхідно переводити у бали. У [9] наведено повний перелік рейтингових показників, кі- 
лькість балів за вид роботи або формули розрахунку балу за відповідним показником з врахуванням долі особистої участі працівника.

Для забезпечення можливості порівнювати рейтингові показники співробітників, які працювали на частину ставки або неповний навчальний рік, здійснюється нормування даних. Вважається, що тривалість навчального року складає 10 місяців.

Бали працівника за досягнення у навчально-методичній $R_{(H-м) \Pi}$, науковоінноваційній $R_{(H-i) \Pi}$, організаційно-виховній роботі $R_{(o-8) \Pi}$ розраховуються у такий спосіб:

$$
\begin{gathered}
R_{(H-M) \Pi}=\frac{10}{m \cdot t} \sum_{k} r_{(H-M)_{k}} ; R_{(H-i) \Pi}=\frac{10}{m \cdot t} \sum_{p} r_{(H-i) p} ; \\
R_{(o-B) \Pi}=\frac{10}{m \cdot t} \sum_{n} r_{(o-B)},
\end{gathered}
$$

де $r_{(H-M)_{k}}, r_{(H-i)_{p}}, r_{(o-8)_{n}}$ - рейтингові показники за навчально-методичною, науково-інноваційною та організаційно-виховною видами робіт, наведені у [9]; $m$ - частина ставки, яку обіймає працівник на посаді; $t$ - кількість відпрацьованих місяців; $k, p, n$ - номер показника за відповідним видом діяльності; $k=\overline{1, K} ; p=\overline{1, P} ; n=\overline{1, N}$.

Важливим інструментом під час оцінювання діяльності науковопедагогічного працівника є опитування студентів, яке дозволяє оперативно отримувати оцінки та пропозиції щодо якості освітніх послуг від зацікавлених учасників освітнього процесу. Відповідне анонімне анкетування студентів організовується та проводиться бюро із забезпечення якості вищої освіти та освітньої діяльності факультету двічі на навчальний рік до початку екзаменаційних сесій. У [10] наведено перелік питань анкети, за допомогою яких студентам можуть оцінити викладача як фахівця у певної галузі знань, визначити його рівень володіння методикою викладання та здатність застосовувати сучасні методи навчання.

Значення показника балів за наслідками анкетування студентів $R_{C П}$ розраховується у такий спосіб:

$$
R_{C \Pi}=\frac{1}{S} \sum_{s=1}^{S} R_{C \Pi_{S}}
$$

де $S$ - кількість студентів, яких було опитано; $R_{C \Pi_{S}}$ - сума балів за відповідною анкетою з номером $s$.

Після визначення рейтингових показників, за якими буде здійснюватися оцінювання, необхідно обрати метод отримання інтегральної оцінки. У літературі існує велика кількість таких методів. Частина з них, наприклад, метод відстаней, передбачають порівняння об'єктів 3 еталоном або об'єктом, який має найвищі показники за компонентами інтегральної оцінки. Також можна 
застосовувати експертні методи, метод компонентного аналізу, метод двовимірного шкалування. Застосування таких методів ускладнюється необхідністю залучення експертів для надання попередніх оцінок щодо еталону та визначення метрик, за якими буде здійснюватися порівняння.

Більш простими у реалізації є методи, які грунтуються на підсумовуванні рейтингових балів, - метод сум або метод суми місць, 3 подальшим ранжуванням отриманих результатів. Метод суми передбачає підсумовування фактичних значень рейтингових балів та ранжування НПП за зменшенням сумарного балу. Недоліком зазначеного методу $є$ те, що окремий НПП може отримати значну перевагу над іншими лише за одним з видів діяльності, наприклад, з науково-інноваційної роботи, при незначних результатах за іншими видами діяльності. Тому при підрахунку рейтингової оцінки запропоновано використовувати саме метод суми місць за видами діяльності.

Метод суми місць передбачає попереднє ранжування всіх НПП за кожним з інтегрованих видів професійної діяльності. За значеннями отриманих рейтингових балів визначається відповідне місце, що займає НПП серед всіх інших у кожному з видів діяльності. Далі для кожного НПП визначається підсумковий рейтинговий бал як сума місць у рейтингах за кожним з видів професійної діяльності у такий спосіб:

$$
P_{\Pi}=\alpha P_{(H-M) \Pi}+\beta P_{(H-i) \Pi}+\gamma P_{(o-\beta) \Pi},
$$

де $\alpha, \beta, \gamma$-вагові коефіцієнти, із застосуванням яких можна збільшити вагу обраного виду діяльності, який зараз $є$ пріоритетним для закладу освіти.

Рейтингова оцінка професійної діяльності керівника підрозділу (завідувача кафедри, декана) розраховується як $P_{K}=\frac{1}{2}\left(P_{O K}+P_{\Pi \Pi}\right)$, де $P_{O K}-$ особистий рейтинговий бал керівника за видами діяльності; $P_{П П}-$ середнє арифметичне значення підсумкових рейтингових балів інших НПП підрозділу.

Список НПП з підсумковими рейтинговими балами впорядковується за зростанням значень, що дозволяє виконати ранжування рейтингових оцінок за критеріями: загальним рейтингом, видами діяльності, групами посад тощо.

Розробка інформаційної системи. Для обробки, аналізу та узагальнення інформації щодо рейтингового оцінювання професійної діяльності НПП ДНУ створюється інформаційна система «Рейтинг викладача». База даних системи формується шляхом обробки персональних рейтинг-листів, які містять актуальні для даного НПП рейтингові показники за видами діяльності.

Серверна частина функціонує в хмарному середовищі Digital Ocean на базі операційної системи Ubuntu 20.04, загальні елементи кодової бази реалізовано з використанням Python 3.9, фреймворк Django Web Framework 3.2, реляційної бази даних SQLite3. Сервер облаштовано SSL сертифікатом, який відповідає вимогам безпеки сучасних браузерів, та надає можливість авторизуватись за допомогою технології OAuth2 через MS Office 365.

Додаток має адаптоване відображення як на мобільних пристроях, так і на стаціонарних комп'ютерах із збереженням функціональних можливостей. 
Аналіз результатів застосування методики рейтингового оцінювання. Розроблену методику та відповідне програмне забезпечення впроваджено у діяльність ДНУ. За результатами збору персональних рейтинг-листів отримано 729 анкет, серед яких 679 виявились повністю заповненими, частково заповнені анкети не розглядались. У табл. 1 наведено узагальнені дані за групами посад, аналізувались мінімальне, максимальне та середнє значення суми місць за видами діяльності, які обчислювались за розробленою методикою. 3 аналізу таблиці можна бачити, що найвищі позиції у рейтингу отримано викладачами незалежно від групи посад, перше друге та третє місце у рейтингу посідають професор, доцент та викладачу відповідно, що свідчить про можливість застосування розробленої методики для об'єктивного оцінювання результатів роботи за всіма групами посад.

\begin{tabular}{|c|c|c|c|}
\hline $\begin{array}{c}\text { група посад } \\
\text { (кількість } \\
\text { анкет) }\end{array}$ & $\begin{array}{c}\text { мінімальне значення суми } \\
\text { місць (місце НПП у рейтин- } \\
\text { гу за загальним результатом } \\
\text { ранжування) }\end{array}$ & $\begin{array}{c}\text { максимальне значення суми } \\
\text { місць (місце НПП у рейтингу за } \\
\text { загальним результатом ранжу- } \\
\text { вання) }\end{array}$ & $\begin{array}{c}\text { середнє значення суми } \\
\text { місць }\end{array}$ \\
\hline $\begin{array}{c}\text { декан } \\
(14)\end{array}$ & $741,4(44)$ & $1493,6(304)$ & 1042 \\
\hline $\begin{array}{c}\text { завідувач } \\
\text { кафедри (59) }\end{array}$ & $596,9(19)$ & $1968,9(540)$ & 1133,3 \\
\hline $\begin{array}{c}\text { професор } \\
(85)\end{array}$ & $170(1)$ & $2487(665)$ & 1441,6 \\
\hline $\begin{array}{c}\text { доцент } \\
(407)\end{array}$ & $250(2)$ & $2692(678)$ & 1427,5 \\
\hline $\begin{array}{c}\text { старший ви- } \\
\text { кладач } \\
(55)\end{array}$ & $561(14)$ & $2674(677)$ & 1628,4 \\
\hline $\begin{array}{c}\text { викладач } \\
(30)\end{array}$ & $297(3)$ & $2510(669)$ & 1834,5 \\
\hline $\begin{array}{c}\text { Асистент } \\
(37)\end{array}$ & $723(38)$ & $2734(679)$ & 1683,7 \\
\hline
\end{tabular}

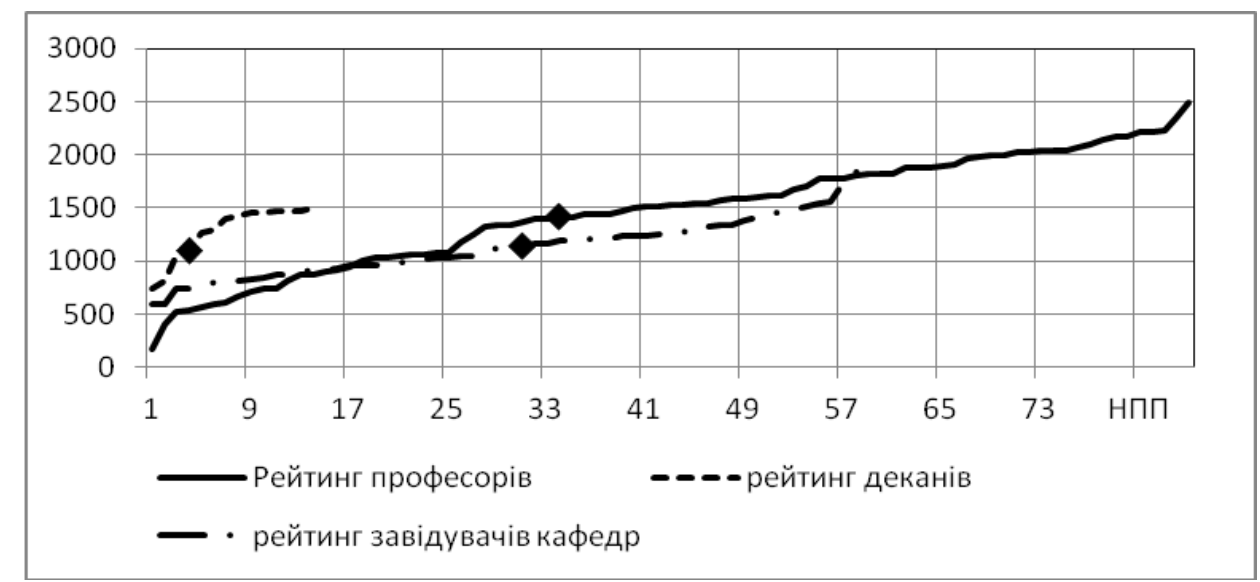

Рис. 1. Рейтинг деканів, завідувачів кафедр, професорів

Однак, за середнім значенням суми місць групи посад суттєво відрізняються. Це пояснюється тим, що у рейтингових показниках наявні певні види робіт, які може виконувати лише працівник з науковим ступенем або керівник підрозділу. Тому середнє значення суми місць для груп посад керівного складу, а також професорів, доцентів значно вище, ніж в групах викладачів 
та асистентів. Із застосуванням знайдених середніх значень за групами посад можна співставити рейтинг окремого НПП з середнім значенням рейтингу у своєї групі. На рис. 1 для порівняння наведено значення рейтингів деканів, завідувачів кафедр та професорів. Можна зазначити, що середні значення рейтингів (позначені маркером ) для кожної з груп посад відрізняються несуттєво, але мінімальні бали, які отримали групи керівних посад, значно вище, ніж значення у групі професорів. Це пояснюється тим, що рейтинговий бал деканів та завідувачів кафедр розраховується з використанням середнього значення рейтингів всіх НПП факультету (кафедри), що впливає на значення особистого рейтингового балу керівника підрозділу. Було проаналізовано, як впливає метод отримання інтегрованої рейтингової оцінки - метод суми місць.

\begin{tabular}{|c|c|c|c|c|c|c|c|c|}
\hline 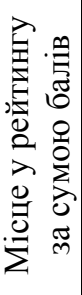 & 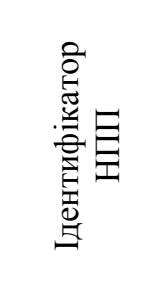 & 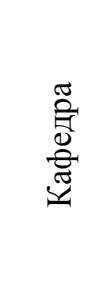 & 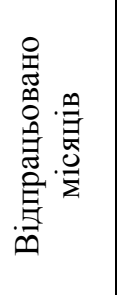 & 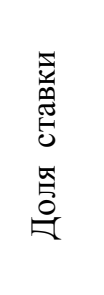 & 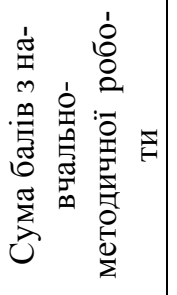 & 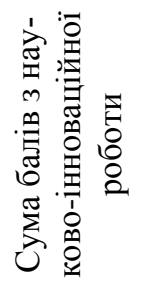 & 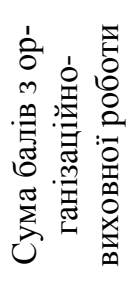 & 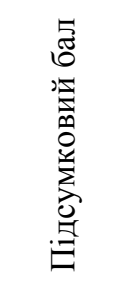 \\
\hline 1 & НПП 1 & XФX & 5 & 0.5 & 1010.76 & 3168 & 540 & 4718.76 \\
\hline 2 & НПП 2 & КЕФ & 10 & 0.2 & 1648.25 & 2245 & 50 & 3943.25 \\
\hline 3 & НПП 3 & ХФX & 10 & 0.5 & 1728.04 & 1366 & 820 & 3914.04 \\
\hline 4 & НПП 4 & $\mathrm{CCO}$ & 10 & 0.75 & 953.52 & 1884 & 360 & 3197.52 \\
\hline 5 & НПП 5 & УзС & 10 & 1 & 613.26 & 1786 & 515 & 2914.26 \\
\hline 6 & НПП 6 & КПР & 10 & 0.25 & 1451.04 & 1384 & 0 & 2835.04 \\
\hline 7 & НПП 7 & TCA & 10 & 0.5 & 639.42 & 1928 & 180 & 2747.42 \\
\hline 8 & НПП 8 & КПР & 10 & 0.5 & 905.22 & 720 & 850 & 2475.22 \\
\hline 9 & НПП 9 & КЕФ & 10 & 0.725 & 1669.56 & 755.1 & 41.38 & 2466.04 \\
\hline 10 & НПП 10 & КЕФ & 10 & 0.5 & 1426 & 533.6 & 450 & 2409.6 \\
\hline
\end{tabular}

Таблиия 3

\begin{tabular}{|c|c|c|c|c|c|c|c|c|c|c|c|}
\hline 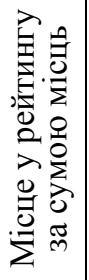 & 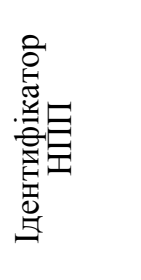 & 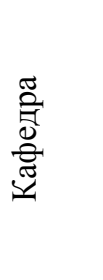 & 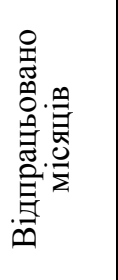 & 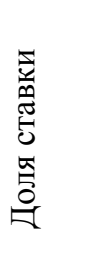 & 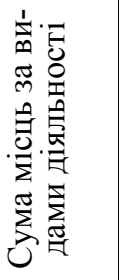 & 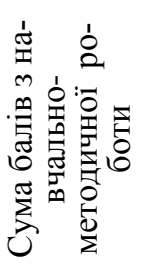 & 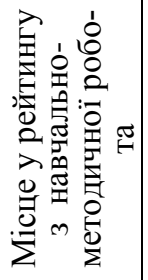 & 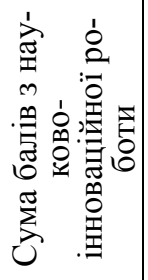 & 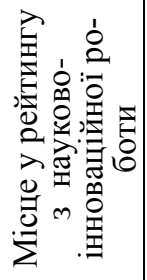 & 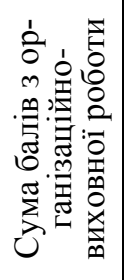 & 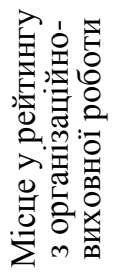 \\
\hline 1 & НПП 3 & ХФX & 10 & 0.5 & 170 & 1728.04 & 19 & 1366 & 13 & 820 & 138 \\
\hline 2 & НПП 8 & КПР & 10 & 0.5 & 402 & 905.22 & 251 & 720 & 27 & 850 & 124 \\
\hline 3 & НПП 1 & ХФХ & 5 & 0.5 & 528 & 1010.76 & 189 & 3168 & 1 & 540 & 338 \\
\hline 4 & НПП 10 & КЕФ & 10 & 0.5 & 532 & 1426 & 54 & 533.6 & 46 & 450 & 432 \\
\hline 5 & НПП 19 & ЕМФ & 10 & 1 & 565 & 960.52 & 218 & 513 & 49 & 575 & 298 \\
\hline 6 & НПП 18 & ПМЗ & 10 & 1 & 594 & 1161.12 & 138 & 386 & 86 & 505 & 370 \\
\hline 7 & НПП 25 & $\mathrm{CПО}$ & 10 & 1 & 602 & 812.26 & 328 & 431 & 64 & 680 & 210 \\
\hline 8 & НПП 24 & ЕФБ & 10 & 1 & 662 & 1098.06 & 156 & 373.8 & 96 & 470 & 410 \\
\hline 9 & НПП 22 & КПР & 10 & 0.5 & 712 & 1223.2 & 104 & 366 & 100 & 410 & 508 \\
\hline 10 & НПП 23 & EKI & 10 & 1 & 736 & 857.97 & 289 & 637 & 35 & 470 & 412 \\
\hline
\end{tabular}


Для порівняння у табл.2 та табл.3 наводяться результати ранжування НПП з групи посад «професори» (наводяться перші 10 записів), які отримано методом суми, коли загальний рейтинг визначається як сума абсолютних балів за кожним з видів діяльності, та методом суми місць відповідно. Аналіз табл. 2 показав, що перші місця посідають НПП, які мають значну перевагу за одним або двома видами робіт. 3 аналізу табл. 3 можна бачити переваги обраної методики розрахунку - місця у рейтингу, отриманому за сумою місць, у порівнянні з табл. 2 мають суттєвий перерозподіл. Перші місця посідають НПП, які мають найвищі місця за всіма видами діяльності.

Висновки. Запропоновано методику рейтингового оцінювання НПП. Розроблено систему цільових показників для навчально-методичної, науковоінноваційної та організаційно-виховної робіт. Інтегрована оцінка розраховується методом суми місць у рейтингах за кожним з видів професійної діяльності. Врахування вагових коефіцієнтів дозволяє визначати пріоритетні напрями діяльності закладу вищої освіти. Розроблено та впроваджено інформаційну систему, здійснено аналіз отриманих результатів.

\section{Бібліографічні посилання}

1. Закон України «Про освіту» від 05.09.2017 № 2145-19 [Електронний ресурс]. Режим доступу: http://zakon2.rada.gov.ua/ laws/show/2145-19/.

2. Закон України «Про вищу освіту» від 01.07.2014 № 1556-VII зі змінами [Електронний pecypc]. - Режим доступу: http://zakon3.rada.gov.ua/laws/show/1556-18.

3. Стандарти і рекомендації щодо забезпечення якості в Свропейському просторі вищої освіти (ESG) [Електронний ресурс]. Режим доступу: http://surl.li/akvty

4. Крушельницька О.В., Мельничук Д.П. Управління персоналом: навчальний посібник. К.: Кондор, 2003. 296 с.

5. Балабанова Л.В., Сардак О.В. Управління персоналом: навч. посібник. К: ВД Професіонал, 2006. $512 \mathrm{c}$.

6. Малтиз В.В., Тарасенко Ю.В. Оцінка персоналу: сучасні методи та інструменти її проведення. «Економіка та суспільство» Мукачівський державний університет. 2018. Вип. 19. С. 484-489.

7. Зеленський К., Стельмащук Л., Луців І. Рейтингове оцінювання роботи викладача як фактор підвищення його конкурентоспроможності. Галищький економічний вісник. 2017. № 2 (53). С. 36-48.

8. Косач, Н.І., Бондаренко Г.Г. Комплексне оцінювання діяльності НПП. Метрологія та прилади. 2018. № 5. С. 67-72.

9. Положення про порядок організації та проведення рейтингової оцінки наукової діяльності наукових та науково-педагогічних працівників ДНУ [Електронний ресурс]. Режим доступу: https://www.dnu.dp.ua/docs/dnu/poloz_reit_npp.doc

10. Положення про якість освіти ДНУ: [Електронний ресурс]. - Режим доступу: https://www.dnu.dp.ua/docs/dnu/polozhennya/Polozhennya_Yakist'_osvity_DNU_2020.pdf

Надійшла до редколегії 31.08.2021. 